\title{
Distribution of crown fracture in anterior teeth of the children with cerebral palsy
}

\author{
Liariza Sativa*, Syarief Hidayat*, Arlette Suzy Puspa Pertiwi Setiawan* \\ *Department of Pedodontics, Faculty of Dentistry, Universitas Padjadjaran
}

\begin{abstract}
Introduction: Crown fracture is a fracture involving enamel only or enamel and dentin with or without pulp exposure. Crown fracture in children may disrupt the speaking and masticating function, aesthetics, and permanent tooth eruption. The condition of the oral cavity of patients with cerebral palsy (CP) characterized by increased frequency of tooth fracture. Purpose of study is to examine distribution of crown fracture anterior teeth of children with cerebral palsy. Methods: Type of research was descriptive. Sample collected by Total Sampling. The sample numbers were 43 children with cerebral palsy. Data were obtained by clinical examination. WHO classification about crown fracture was used to evaluate oral and dental hygiene. Results: The result of this study showed that 39 children $(90,7 \%)$ had crown fractures in anterior teeth. The 39 children consisted of 22 boys (51,17\%), 17 girls (39,53\%). Crown fracture in anterior teeth of the children with cerebral palsy is $60,47 \%$ in the upper jaw. Conclusion: The fracture of the anterior crown of the anterior teeth that are found is the fracture in the enamel. The anterior crown fracture is more common in boys and is found in maxillary anterior teeth of maxillary incisors.
\end{abstract}

Keywords: Crown fracture in anterior teeth, cerebral palsy.

\section{INTRODUCTION}

Among humans who live on this earth, not all are in a healthy physical and/or mental state. Health includes four aspects, which are physical (mental), mental (social), social, and economic aspects (Health Act No. 23 of 1992). According to the National Census Bureau of Statistics 2003 data, the number of handicapped persons in Indonesia is $0.7 \%$ of the total population of $211,428,572$ or 1.480 .000 people. The number of children with school-specific needs in 2007 to 321,000 children using baseline data in 2003, then proportionally projected. $^{1}$

The Department of Health, Education, and
Welfare of the United States, in its Rehabilitation Act (1973) defines handicapped sufferers as the person with physical or mental disorders (who experience limitations such as limited mobility, walking, seeing, listening, speaking, breathing, learning, and work).

Dental conditions for handicapped children may relate directly or indirectly to physical and mental disabilities. Some of the things that cause such handicapped conditions, including congenital heart disease, cleft lip, and palate, cerebral palsy $(\mathrm{CP})$, epilepsy, bleeding disorders (hemophilia), and down syndrome.

$\mathrm{CP}$ is one example of handicapped conditions due to physical and mental disability. ${ }^{2}$ 
Literally, cerebral is brain and palsy is paralysis. $\mathrm{CP}$ is not a contagious or hereditary disease but a nonprogressive neuromuscular disorder caused by brain damage that can occur during the prenatal, perinatal and postnatal period. ${ }^{3} \mathrm{CP}$ is a disorder or abnormality that occurs over a period of time in a child's development of the motoric cells in the central nervous system, are chronic and not progressive due to abnormalities in brain tissue of unfinished growth. ${ }^{4}$

The incidence rate of $\mathrm{CP}$ in children is estimated to be 1.2-2.5 children per 1000 live birth. 5 The category of children according to Child Protection Law No. 23 year 2002 is a man/woman since in the womb until before the age of 18 years. ${ }^{6,7}$ Overview of children with $\mathrm{CP}$, including involuntary movements, seizures, mental retardation, sensory impairment, delayed development of motor skills, learning and emotional disturbances, speech and communication disorders, emotional disturbances, visual impairment. ${ }^{2,8}$

The condition of the oral cavity of patients with CP characterized by increased frequency of the periodontal disease, gum hyperplasia, increased caries, bruxism, dental attrition, enamel hypoplasia, malocclusion, mouth breathing, TMJ disorders, poor oral hygiene, saliva secretion (drooling), and tooth fracture. , $^{2,3}$

A tooth fracture is the disappearance or loss of fragments of an intact tooth caused by trauma or impact. Approximately $82 \%$ of teeth with fractures are the teeth of the upper jaw. The fracture of the maxillary tooth is $64 \%$ central incisor, $15 \%$ lateral incisive, and $3 \%$ canine. $^{9}$

Ellis and Davey report that of 4251 school children in large cities, $4.2 \%$ had an anterior fracture. 2 The CP sufferer was easier tooth fractures, especially in the maxillary anterior teeth. ${ }^{2,10,9}$ Fractures in the dental crown may involve enamel, dentine, and pulp. ${ }^{11}$ Psychologically, early tooth loss, especially the anterior teeth will cause the disturbance in children and parent.

The child may withdraw him or her self from the society and surroundings due to embarrassment or lack of confidence in appearance. It will interfere with the interactions of children with those around them and reduce the activity of children to develop themselves. ${ }^{12}$ Parents often feel guilty about the inability of their children and cause parents to often feel angry, sad, excessive rejection and protective of a child's relationship with the world of education and existing clinical staff. ${ }^{13}$ In addition, anterior teeth that prematurely may affect speech function, mastication, and causing compacted teeth. ${ }^{14,15,16}$

Dentist plays an important role in a multidisciplinary approach in $\mathrm{CP}$ patient care services accompanied by neuromuscular disorders. Early and routine dental and oral examination and treatment may improve the oral and dental health of CP's children.

Seventeen Data from Sekolah Luar Biasa bagian D Yayasan Pembinaan Anak Cacat in 2009 shows the number of $\mathrm{CP}$ sufferers as much as $88.68 \%$ of the total pupil, while the rest is autistic. Purpose of study is to examine distribution of crown fracture anterior teeth of children with cerebral palsy.

\section{METHODS}

The type of research used is descriptive with survey technique. The study was conducted through clinical examination and filling questionnaire. The data of the research were collected, processed, and presented in tabular form and diagrams to obtain the description of anterior teeth fracture of CP children in the Sekolah Luar Biasa bagian D Yayasan Pembinaan Anak Cacat Kecamatan Sukajadi Kota Bandung

data analyzed using of percentage of anterior teeth fracture of child CP by sex, classification World Health Organization (WHO), the location of the affected tooth fracture, and the location of the affected tooth of the tooth fracture.

Population in this research is CP children in Sekolah Luar Biasa bagian D Yayasan Pembinaan Anak Cacat Kecamatan Sukajadi Kota Bandung (picture 3.1), with sample counted 43 children. The study was conducted by total sampling technique with criteria of children under the age of 18 years.

Data obtained from the results of the study were collected, recorded, evaluated and then arranged in the form of tables and diagrams to find out the anterior dental fracture fracture in CP children in the Sekolah Luar Biasa bagian D Yayasan Pembinaan Anak Cacat Kecamatan Sukajadi Kota Bandung. 


\section{RESULTS}

The study of anterior chest fracture image of CP children was done in the Sekolah Luar Biasa bagian D Yayasan Pembinaan Anak Cacat Kecamatan Sukajadi Kota Bandung. The study was conducted in November 2009. The results obtained by the number of samples of 43 people. The sample consisted of 24 boys and 19 girls. The classification used is the WHO (World Health Organization) classification.

Table 1. Distribution of Child with Cerebral Palsy experiencing anterior dental crown fracture

\begin{tabular}{ccc}
\hline \multicolumn{1}{c}{ Detail } & $\begin{array}{c}\mathrm{n} \\
\text { (Subject) }\end{array}$ & $\begin{array}{c}\text { Percentage } \\
\text { (\%) }\end{array}$ \\
\hline $\begin{array}{l}\text { Experiencing anterior dental } \\
\text { crown fracture Not experiencing }\end{array}$ & 39 & 90,70 \\
anterior dental crown fracture & 4 & 9,30 \\
\hline \multicolumn{1}{c}{ Total } & 43 & 100 \\
\hline
\end{tabular}

Tabel 4.1 shows that $\mathrm{CP}$ children in the Sekolah Luar Biasa bagian D Yayasan Pembinaan Anak Cacat as many as 43 children. The results of the study on 43 children obtained 39 children CP who exposed anterior teeth fracture. While the CP child who is not exposed to anterior teeth fractures as many as 4 children.
Table 2. Distribution of Child with Cerebral Palsy experiencing anterior dental crown fracture

\begin{tabular}{ccc}
\hline Gender & $\begin{array}{c}\mathrm{n} \\
\text { (Subject) }\end{array}$ & $\begin{array}{c}\text { Percentage } \\
\text { (\%) }\end{array}$ \\
\hline Boys & 22 & 56,41 \\
Girls & 17 & 43,59 \\
\hline Total & 39 & 100 \\
\hline
\end{tabular}

Table 3. Distribution of Anterior Dental Fracture of Anterior Children of Cerebral Palsy Based on WHO (World Health Organization)

\begin{tabular}{ccc}
\hline $\begin{array}{c}\text { Dental Crown Fracture based } \\
\text { on WHO classification }\end{array}$ & $\begin{array}{c}\text { Total of } \\
\text { fracture }\end{array}$ & $\begin{array}{c}\text { Percentage } \\
\text { (\%) }\end{array}$ \\
\hline Enamel crack & 22 & 56,41 \\
Enamel fracture & 17 & 43,59 \\
Enamel-dentin fracture & 39 & 100 \\
Complex fracture & 1 & 1,76 \\
\hline Total & 57 & 100 \\
\hline
\end{tabular}

Table 4.2 shows that out of $43 \mathrm{CP}$ children in the Sekolah Luar Biasa bagian D Yayasan Pembinaan Anak Cacat Kecamatan Sukajadi Kota Bandung, there are $39 \mathrm{CP}$ children affected by anterior crown fracture. The anterior crown fracture may affect boys and girls. The number of anterior crown fractures in boys, ie 22 children $(56.41 \%)$ and in girls ie 17 children (43.59\%).

Tabel 4. Distribution of Anterior Dental Fractures of Cerebral Palsy Children by Type of Teeth Affected with Anterior Dental Fracture

\begin{tabular}{|c|c|c|c|c|c|c|}
\hline \multirow{2}{*}{ Tooth } & \multicolumn{4}{|c|}{ Dental Crown Fracture based on WHO classification } & \multirow{2}{*}{ Total of fracture } & \multirow{2}{*}{$\begin{array}{c}\text { Percentage } \\
\text { (\%) }\end{array}$} \\
\hline & Enamel crack & Enamel fracture & Enamel-dentin fracture & Complex fracture & & \\
\hline 1.1 & 1 & 8 & 6 & 1 & 16 & 28.07 \\
\hline 1.2 & 0 & 3 & 1 & 0 & 4 & 7.02 \\
\hline 1.3 & 0 & 0 & 3 & 0 & 3 & 5.26 \\
\hline 2.1 & 1 & 6 & 4 & 0 & 11 & 19.29 \\
\hline 2.2 & 1 & 4 & 2 & 0 & 7 & 12.28 \\
\hline 2.3 & 0 & 2 & 0 & 0 & 2 & 3.50 \\
\hline 3.1 & 2 & 2 & 1 & 0 & 5 & 8.77 \\
\hline 3.2 & 0 & 3 & 2 & 0 & 5 & 8.77 \\
\hline 3.3 & 0 & 0 & 1 & 0 & 1 & 1.76 \\
\hline 4.1 & 0 & 1 & 0 & 0 & 1 & 1.76 \\
\hline 4.2 & 0 & 1 & 0 & 0 & 1 & 1.76 \\
\hline 4.3 & 0 & 0 & 1 & 0 & 1 & 1.76 \\
\hline & Total & & & & 57 & 100 \\
\hline
\end{tabular}




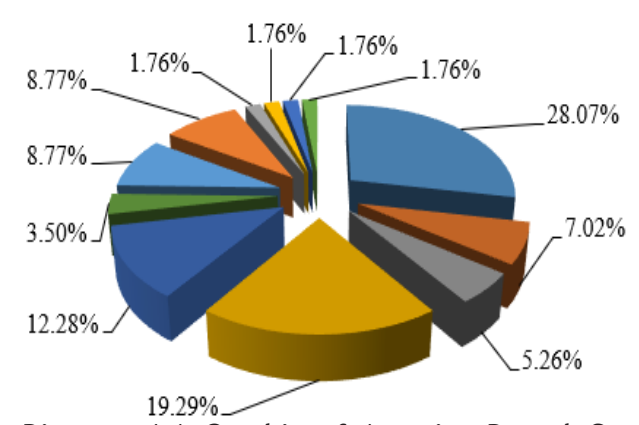

- Teeth 1.1

- Teeth 1.2

Teeth 1.3

Teeth 2.1

" Teeth 2.2

- Teeth 2.3

- Teeth 3.1

- Teeth 3.2

- Teeth 3.3

In 4.1

- Teeth 4.2

- Teeth 4.3

Diagram 4.1 Graphic of Anterior Dental Crown Fracture of Cerebral Palsy children at Sekolah Luar Biasa bagian D Yayasan Pembinaan Anak Cacat Kecamatan Sukajadi Kota Bandung based on the tooth area affected by Danteriot Dental Fracture.



Diagram 2. Graphic of dental crown fracture of CP child in Sekolah Luar Biasa Bagian D Yayasan Pembinaan Anak Cacat Kecamatan Sukajadi Kota Bandung

The result of the research from diagram 4.2 concerning anterior crown fracture in $\mathrm{CP}$ child in Sekolah Luar Biasa bagian D Yayasan Pembinaan Anak Cacat Kecamatan Sukajadi Kota Bandung according to the location of teeth on jaw teeth obtained that maxillary teeth exposed anterior teeth fracture as much as $75,44 \%$. While the percentage of the teeth on the lower jaw is $24.54 \%$. The anterior teeth of the upper jaw are more at risk for the occurrence of anterior crown

Table 5. Distribution of Cerebral Palsy Type that undergoes Anterior Dental Crown Fracture

\begin{tabular}{ccc}
\hline Type of Cerebral Palsy & Total of fracture & $\begin{array}{c}\text { Percentage } \\
\text { (\%) }\end{array}$ \\
\hline Spastics & 36 & 56,41 \\
Athetoid & 19 & 43,59 \\
Ataxia & 1 & 2 \\
Mix & 1 & 2 \\
\hline Total & 57 & 100 \\
\hline
\end{tabular}

fractures.

The result of the study from table 4.5 shows that $\mathrm{CP}$ children who have anterior tooth fracture according to CP type are often found at SLB D
YPAC Kecamatan Sukajadi Kota Bandung, there are 36 spastic fractures, 19 occurrences of fractures of athetoid type, 1 fracture occurrence of ataxia type, and 1 fracture occurrence in mixed type

\section{DISCUSSION}

The study of 43 children of CP in the Sekolah Luar Biasa bagian D Yayasan Pembinaan Anak Cacat Kecamatan Sukajadi Kota Bandung showed that the anterior crown fracture percentage in CP child was 39 children $(90,7 \%)$ and 4 children did not have the anterior crown fracture (table 4.1 ). This is in accordance with research Paradipta. Table 4.2 shows that of the $39 \mathrm{CP}$ children exposed to anterior crown fractures, 22 boys (51.17\%) and 17 girls $(39.53 \%)$ had fractured anterior crowns. Koch and Poulsen (2001) found that anterior crown fractures were more common in boys than girls, with a ratio of $2: 1$. This is in accordance with the results of research conducted.

The high percentage of crown fracture of anterior teeth in children with $\mathrm{CP}$ is associated with CP condition that often falls, the enamel hypoplasia, abnormal movement function in the mouth area so that the patient closes his jaw by force, uncontrolled and the teeth become fracture on the incisal part of the tooth, protrusive teeth. $18,8 \mathrm{CP}$ children have a tendency to fall due to uncoordinated motion movements, which may result in fracture of the anterior teeth. The presence of malocclusion in patients with $\mathrm{CP}$ can also be a factor supporting the occurrence of tooth fracture. Children with Class II malocclusion (protrusive tooth) have 2-3 times risk for anterior tooth fracture. ${ }^{2,3}$ Results conducted on 23 CP children in the Sekolah Luar Biasa bagian D Yayasan Pembinaan Anak Cacat Kecamatan Sukajadi Kota Bandung shows that the percentage of malocclusion based on Angle classification on CP child reaches $95.65 \%$. Thirteen children (56.52\%) were protrusive in maxillary anterior teeth. ${ }^{19}$

The most common tooth fractures are the maxillary teeth of $82 \%$, consisting of $64 \%$ in the central incisive, $15 \%$ in the lateral incisors, and 3\% in the canine. 9 The results of the study in Diagram 4.2 show that 39 children who had anterior tooth fracture with 57 fracture incidence were found $75,44 \%$ anterior crown fracture occurred at maxilla and $24,54 \%$ occurred at lower jaw. Table 
4.4 and diagram 4.1 show that from 57 incidences of anterior crown fracture in CP child in Sekolah Luar Biasa bagian D Yayasan Pembinaan Anak Cacat Kecamatan Sukajadi Kota Bandung there are $28,07 \%$ fracture of maxillary right incisive dental crown, $7.02 \%$ of teeth right maxillary right incisor, $5.26 \%$ maxillary right canine, $19.29 \%$ maxillary left central incisor, $12.28 \%$ maxillary left lateral incisor, $3.50 \%$ maxillary left canine. There is an anterior dental fracture of $8.77 \%$ central incisor and right mandibular right incisor, $1.76 \%$ of mandibular right canine teeth.

The fracture of the mandibular left anterior teeth has the same percentage, which is $1.76 \%$. This suggests that the maxillary central incisors are susceptible to fracture. This occurs because the position of the maxillary anterior teeth is more inclined toward the labial than the lower jaw so that the possibility of fracture is also greater. ${ }^{20}$

The result of the research from table 4.5 shows that $\mathrm{CP}$ children who have anterior tooth fracture according to CP type are often found in SLB D YPAC Kecamatan Sukajadi Kota Bandung obtained 36 incidence of fracture in spastic type, 19 incidence of fracture on athetoid type, 1 fracture occurrence at ataxia type, and 1 incidence of fracture in mixed type. It shows that anterior crown fracture sufferers in the majority are the spastic type. Most of CP sufferers use tools to help their mobility like the wheelchair.

The result of the questionnaire conducted on 43 children of CP in Sekolah Luar Biasa bagian D Yayasan Pembinaan Anak Cacat Kecamatan Sukajadi Kota Bandung obtained 10 children (23.26\%) who can play, run run, and chase. This is because children have limitations in terms of movement so that children can only sit and do activities using a wheelchair. ${ }^{5}$ Results of CP questionnaires who can play, run, and chase obtained $10 \mathrm{CP}$ children who had fallen during playing with frequencies 1-3 times a day and about $80 \%$ of children who fall are fractured on their teeth.

Another contributing factor that causes fracture of the anterior teeth is due to an impact on the child's teeth. It was found in 30 children (67.44\%) of the questionnaire with 29 children (93.55\%) who had fractures on the anterior teeth. Generally, these children experience a conflict around the age of 1-5 years. The age of 1-3 years when children learn to walk and run incidents increased due to high activity and lack of coordination of the limb causing the child to fall frequently. 22 The results of the questionnaire showed, from 31 children there were 22 children $(70,97 \%)$ who experienced a conflict around the age of 1-5 years. Only a small proportion of CP children had a fracture of the anterior teeth due to hard food, which was about 7 children (16.28\%). Questionnaire results found 19 children CP (44.19\%) who experienced bruxism. Bruxism occurred in just a few seconds and from 19 children who experienced bruxism, found 9 children CP (47.37\%) who experienced tooth fracture. Bruxism occurs because of emotional disturbance in children so it can cause tooth wear. Tooth wear also occurs as a result of inadvertent motion or too much contraction of the jawbone control muscles. ${ }^{18}$

According to the results of the study, it was found that 19 children (44.17\%) had difficulties in closing their mouth. Patients with CP often close the jaw by force and uncontrolled movement (?) This situation can cause pressure on the incisal teeth so that the teeth become fractured. Trauma to the teeth when they are still young can affect the hard tissues of teeth, pulp tissue, and tissue around the teeth. An anterior crown fracture is a more common occurrence due to trauma to the permanent tooth. This is because the inclination of the tooth remains more labial and the alveolar bone is denser than the deciduous tooth, so that tooth fracture is more common in permanent teeth. ${ }^{20}$

The damage that occurs in deciduous teeth will disrupt the growth and development of jaw bone. In addition, anterior tooth decay can interfere with the appearance, speech function, and mastication, resulting in a psychological impact on children. The psychological impact that resulted in the child withdraw from the association and the surrounding environment because of embarrassment or lack of confidence in his appearance. ${ }^{12}$

Study on 23 children of $\mathrm{CP}$ showed that 12 children $(52.17 \%)$ never went to the dentist and 10 children $(43.48 \%)$ rarely went to the dentist, only 1 child $(4.35 \%)$ who routinely check the dentist. 19 Early and routine dental and oral examinations and treatment may improve the dental and oral health of CP children. The dental and oral health of CP 
patients can be achieved through routine dental care programs. ${ }^{23,17}$ Dentists play an important role in CP. 17 Patients' health care needs to be prepared and given special skills to handle CP children. The state of the CP child who can not be co-operated during his or her dental care can be physically controlled and premedicated. (?)Should take precedence of dental and oral precautions rather than treatment measures. Because the action of dental and oral care CP child is difficult to do and require a special treatment. It may be an input for relevant agencies to pay more attention to dental and mouth health in handicapped children, especially CP. ${ }^{18}$

\section{CONCLUSION}

The fracture of the anterior crown of the anterior teeth that are found is the fracture in the enamel. The anterior crown fracture is more common in boys and is found in maxillary anterior teeth of maxillary incisors.

\section{REFERENCES}

1. Harijanto S. Mencari Keberadaan Anak Cacat Untuk Memfasilitasi Pendidikannya. 2008

2. Finn SB. Clinical Pedodontics. 4th Ed. Philadelpia. W.B. Saunders Company. 2003. 227, 228, 230, 231, 577, 578 pp.

3. Welbury R. Paediatric Dentistry. New York. Oxford University Press. 2005. 259-261, 265, 425-427 pp.

4. Adnyana IMO. Cerebral Palsy Ditinjau Dari Aspek Neurologi. Cermin Dunia Kedokteran. 1995; 104:34-37 pp.

5. Saharso D. Kuliah Cerebral Palsy Diagnosis dan Tata Laksana. Naskah Lengkap Ilmu Kesehatan Anak XXXVI. 2006; 4-14 pp.

6. Abied. Pengertian Anak, Konsep dan Batasan Anak di Bawah Umur. 2009.

7. Lenakoly S. Angka Kriminal Anak di Bawah Umur. 2009.

8. Paradipta. Penanganan Kesehatan Gigi dan Mulut pada Anak yang Menderita Cacat Mental. 2009.
9. Adell, bahrudin T. Perawatan gigi fraktur dengan mahkota. PT. Gakken: Health and education indonesia. 2009. 1-6 pp.

10. Care J. Pemeriksaan Radiografi Pada Penyakit Periodontal. 2008.

11. Pinkham JR. Pediatric Dentistry Infancy Through Adolescence. $4^{\text {th }}$ Ed. St. Louis, Missouri. Elsevier Saunders. 2005. 237-240 pp.

12. Rizal MF, Sutadi H. Reposisi kaninus atas akibat trauma (laporan kasus). J Ked Gigi UI. 2003;10(1):36-40 pp.

13. Swash M, Oxbury J. Clinical Neurology. Edinburgh, London, Melbourne, New York, Tokyo. Churchill Livingstone. 1991. 779 pp.

14. Ariyani D. Mengenal Gangguan Bicara pada Anak Cerebral Palsy. 2005.

15. Amal N. Space Maintainer. 2008. 315-317 pp.

16. Imoetida. Dampak Negatif kehilangan Gigi. 2008.

17. Stanford Jr, Thomas W. Cerebral Palsy and Dentistry, A Brief Review. 2000.

18. Irmaleny. Gambaran Tingkat Kebersihan Gigi dan Mulut pada Anak Cerebral Palsy di SLB D Yayasan Pembinaan Anak Cacat. Skripsi. Bandung: Fakultas Kedokteran Gigi Universitas Padjadjaran.1989. 18-21 pp.

19. Mayasari NLN. Gambaran Maloklusi pada Anak Cerebral Palsy Usia 7-15 Tahun di SLB D Yayasan Pembinaan Anak Cacat Kota Bandung Tahun 2007. Skripsi. Bandung. Fakultas Kedokteran Gigi Universitas Padjadjaran. 2007. 22-25 pp.

20. Manovita V. Penggunaan Mouthguard Dalam Usaha Pencegahan Trauma Gigi Anterior pada Anak. Skripsi. Bandung. Fakultas Kedokteran Gigi Universitas Padjadjaran. 2005. 9 pp.

21. National Institute of Neurological Disordes and Stroke (NINDS). Cerebral Palsy: Hope Through Research. 2006.

22. Koch G, Poulsen S. Pediatric Dentistry: A Clinical Approach. Copenhagen: Munksgaard. 2001. 352, 353, 357-360, 365, 366, 368 pp.

23. Sutadi, Heriandi. Masalah Perawatan Gigi dan Mulut Anak Penderita Cerebral Palsy. Jurnal Kedokterran Gigi Universitas Indonesia. 1995. 32, 40-48 pp. 